\section{Setup ultrazvučnog aparata za optimizaciju slike u pregledu fetalnog srca}

\author{
Milan Perović ${ }^{1}$, Amira Fazlagić ${ }^{2}$, Miroslava Gojnić ${ }^{3}$ \\ ${ }^{1}$ Bolnica za ginekologiju i akušerstvo, Kliničko-bolnički \\ „Zemun“- Beograd \\ ${ }^{2}$ Ginekološka ordinacija „Medison plus“, Beograd \\ ${ }^{3}$ Institut za ginekologiju i akušerstvo Kliničkog centra Srbije
}

\section{Apstrakt}

Lekar koji učestvuje u prenatalnom skriningu i dijagnostici kongenitalne srčane bolesti mora biti familijaran sa potencijalnim uticajem tehničkih faktora u postizanju najboljih diagnostičkih prikaza srca i njegovih struktura, a sve u okviru prihvatljivih termalnih i mehaničkih sigurnosnih limita ultrazvučnih procedura u obstetriciji. Znanje adekvatne optimizacije gain-a, uvećanja ultrazvučne slike, korišćenje compound imaging-a i harmonic imaging-a su preduslovi kvalitetnog pregleda. Ostali važni faktori koji utiču na pregled i koji treba da se uzmu u obzir su gestaciona starost u momentu pregleda, maternalni telesni habitus, fetalni pokreti i pozicija i primenjena frekvenca ultrazvučnog talasa. Nekad je neophodno da se sačeka optimalni fetalni položajda bi prikazali željene strukture, a da bi se to postiglo nekad se pacijent mora ponovo pregledati nekom drugom prilikom.

\title{
Setup to optimize the ultrasound image in the view of the fetal heart
}

\author{
Milan Perović1, Amira Fazlagić ${ }^{2}$, Miroslava Gojnićc \\ ${ }^{1}$ Hospital for Gynecology and Obstetrics, Clinical hospital \\ Center "Zemun"- Belgrade, Belgrade, Serbia \\ ${ }^{2}$ Ginecological servis „Medison plus“, Belgrad \\ ${ }^{3}$ Institute of Ginecology, Clinical Center Serbia, Belgrade
}

\begin{abstract}
The examiner must be completely familiar with the potential impact of technical factors for acquiring the best diagnostic heart images within the constraints of acceptable thermal and mechanical safety indices. Ultrasound signal gain, image magnification, compound imaging, and harmonic imaging should be optimized. Other important factors should also be considered, including menstrual age, maternal body habitus, fetal movement and position, and ultrasound transducer frequency. It may be necessary to wait until an optimal fetal position is obtained or even to reschedule the patient to be scanned on another day.
\end{abstract}

Key words: fetal echocardiography, ultrasound setting

Ključne reči: fetalna ehokardiografija, ultrazvučni setting

Lekar koji učestvuje u prenatalnom skriningu i dijagnostici kongenitalne srčane bolesti (KSB) mora biti familijaran sa potencijalnim uticajem tehničkih faktora u postizanju najboljih dijagnostičkih prikaza srca $i$ njegovih struktura, a sve u okviru prihvatljivih termalnih i mehaničkih sigurnosnih limita ultrazvučnih procedura u obstetriciji. Znanje adekvatne optimizacije gain-a, uvećanja ultrazvučne slike, korišćenje compound imaging-a (CI) i tissue harmonic imaging-a (THI) su preduslovi kvalitetnog pregleda. Ostali važni faktori koji utiču na pregled i koji treba da se uzmu u obzir su gestaciona starost u momentu pregleda, maternalni telesni habitus, fetalni pokreti i pozicija, kao i primenjena frekvenca ultrazvučnog talasa. Nekad je neophodno da se sačeka optimalni fetalni položajda bi prikazali željene strukture, a da bi se to postiglo nekad se pacijent mora ponovo pregledati nekom drugom prilikom¹.

\section{Kvalitet slike u ultrazvučnom skriningu i dijgnostici kongenitalne srčane bolesti}

S obzirom da pregled fetalnog srca ima svoje osobenosti (najvažnija je da posmatramo organ koji je stalno u "pokretu") postoji nekoliko stvari koje trebamo promeniti u setingu aparata da bismo dobili optimalan prikaz posmatranih struktura. Dva najvažnija razloga za poznavanje načina pripreme ultrazvučnog aparata su (boldirano):

Mnogi od nas i danas rade na starim aparatima, koji nemaju opciju automatskog setinga za fetalnu ehokardiografiju. Ipak to ne znači da se njima ne može dobiti dobar prikaz fetalnog srca uz preduslov poznavanja načina adekvatnog manuelnog setinga. 
Automatski seting za pregled fetalnog srca (koji poseduju savremeni aparati) je kreiran za optimizaciju slike prosečnog pacijenta. U praksi se srećemo sa pacijentima i situacijama koje odudaraju od "najčešćih", odnosno prosečnih. Primeri su gojazna trudnica, smanjena količina plodove vode ili neadekvatan položaj fetusa, što otežava postavljanje dijagnoze.

Optimizacija kvaliteta slike B-moda gray-scale u pregledu fetalnog srca se postiže:

Povećavanjem kontrasta. Kontrastna rezolucija predstavlja sposobnost jasnog i lakog razlikovanja različitih tipova tkiva ${ }^{2}$ (na primer fetalna pluća se lako razlikuju od fetalne jetre).

Da bi postigli bolju rezoluciju potrebno je koristiti visoke ultrazvučne frekvencije, a njihov raspon će se kretati od 3 do $8 \mathrm{MHz}$ u zavisnosti od gestacione starosti, telesnog habitusa trudnice i količine plodove vode. Visoka frekvenca daje bolju rezoluciju, ali i manju penetraciju talasa. Znači da ćemo koristi najveću moguću frekvenciju za dobar odnos rezolucije i penetracije ${ }^{3}$.

Povećanjem frame rate-a. Ono se postiže povećanjem depth-a, korišćenjem zoom-a i najvažnije sužavanjem ultrazvučnog boxa.

Uvećanim prikazom fetalnog srca i njegovih struktura što se postiže povećanjem depth-a i korišćenjem zoom-a. Potrebno je da se postigne takvo uvećanje slike srca koje nam ispunjava trećinu do polovine ultrazvučnog ekrana ${ }^{4}$.

Korišćenjem adekvatnog insonacionog ugla za posmatranje odgovarajućih struktura. Posmatranje istih struktura iz različitih perspektiva, korišćenjem različitih insonacionih uglova, dobijamo različite infeormacije. Najvažniji primer je četvorokomorni presek srca, koji se može posmatrati posmatrati kao apikalni (Slika 1.) ili subkostalni presek (Slika 2), a iz kojih se crpe različite informacije.

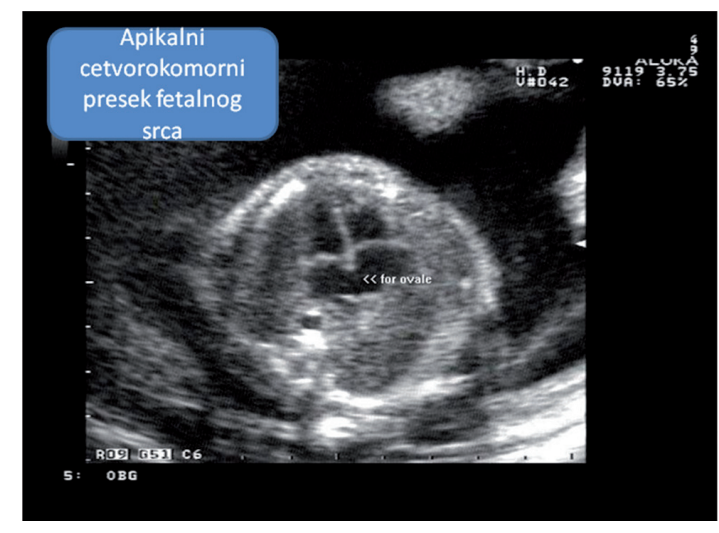

Slika 1. Apikalni presek

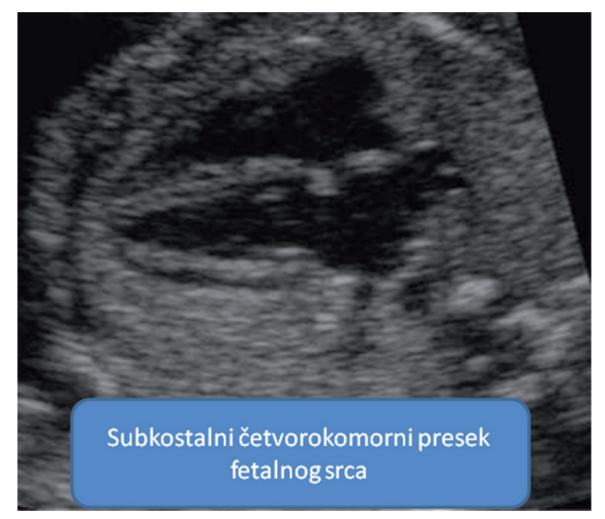

Slika 2. Subkostalni presek

Tako subkostalni služi za upoređivanje i merenje veličine komora i pretkomora srca, debljine komornih zidova i interventrikularnog septuma korišćenjem M-moda, detekciju aritmija M-modom, evaluaciju foramena ovale color i spektralnim Dopplerom, evaluaciju integriteta interventrikularnog septuma u B-modu gray-scale, 
ali i korišćenjem color i spektralnog Dopplera. Sa druge strane apikalni četvorokomorni presek služi za evaluaciju atrioventrikularnih zalistaka, naročito Doppler pregledom koji je baš u ovom preseku najpouzdani, $\mathrm{s}$ obzirom da se može postići Doppler insonacioni ugao od nula ili blizu nula stepeni. Ovim pregledom moguće je postaviti dijagnozu stenoze ili insuficijencije atrioventrikularnih zalistaka. Sa druge strane ovaj presek je neodgovarajući za procenu integriteta interventrikularnog septuma jer je ultrazvučni talas njemu paralelan i može rezultovati artefaktom "ispada, nedostatka" ehoa na nivou membranoznog interventrikularnog septuma, stvarajući na ultrazvučnoj slici "lažni, pseudo" septalni defekt³.

Optimizacija kvaliteta slike doppler pregleda fetalnog srca se postiže:

Inicijalnim korišćenjem visoke puls repetition frequency. Imajući u vidu da je color Doppler sonografija u suštini modifikacija pulsne Doppler tehnike, aliasing se može pojaviti kada posmatrani protok krvi premaši odabrani velocity range. S obzirom na visoke protoke $u$ fetalnom srcu, a da bi izbegli aliasing, na početku pregleda je najbolje koristiti visok high pulse repetition frequency (PRF) seting. Međutim, neki protoci koje moramo sagledati oko i u srcu su niski i zahtevaju nizak PRF seting, kao što su protoci kroz pulmonarne vene, kroz foramen ovale, ali i ventrikularni dijastolni uliv (inflow) i sistolni outflow ukoliko pregledom nije moguće postići adekvatan insonacioni ugao. PRF seting je optimalan kada posmatrani protok krvi kompletno ispunjava posmatrani krvni sud ili srčanu šupljinu i kada se fenomen aliasing-a ne javlja 5 .

Filter high. Doppler signale ne uzrokuje samo kretanje krvi, već i pokreti zidova krvnog suda. Doppler signali porekla zida krvnog suda su tipično visokih amplituda ali niske frekvencije. Za razliku od njih, signal koji rezultuje od protoka samog krvnog suda ima visoke frekvencije i niske amplitude. Zato korišćenje filtera služi za uklanjanje nisko-frekventnih signala ${ }^{6}$.

Treba postaviti nizak persistence. Persistence, koji se još naziva i temporal averaging, vrši uprosečavanje ultrazvučnih slika sukcesivnih frame-ova u cilju redukcije

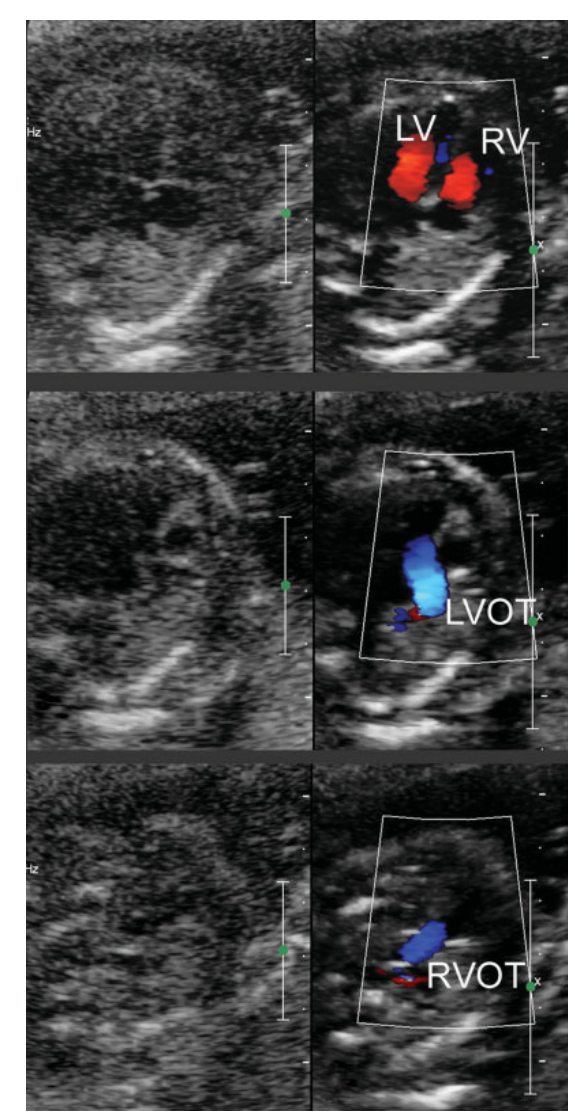

Slika 3. Color Doppler evaluacija pomaže u prikazivanju normalnih atrioventrikularnih i ventrikuloarterijalnih konekcija u slučaju kada gray-scale ne dozvoljava adekvatan pregled usled gojaznosti trudnice. $(a, b, c)$ gray-scale slike četvorokomornog preseka, izlaznog trakta leve (LVOT) i desne komore (RVOT). (d,e,f) Iste strukture prikazane color Dopplerom: normalan uliv krvi u obe komore (d), normalan izgled LVOT-a (e) i RVOT-a i crossingover (f). Laminarni tok demonstriran color Dopplerom isključuje stenozu ili obstrukciju

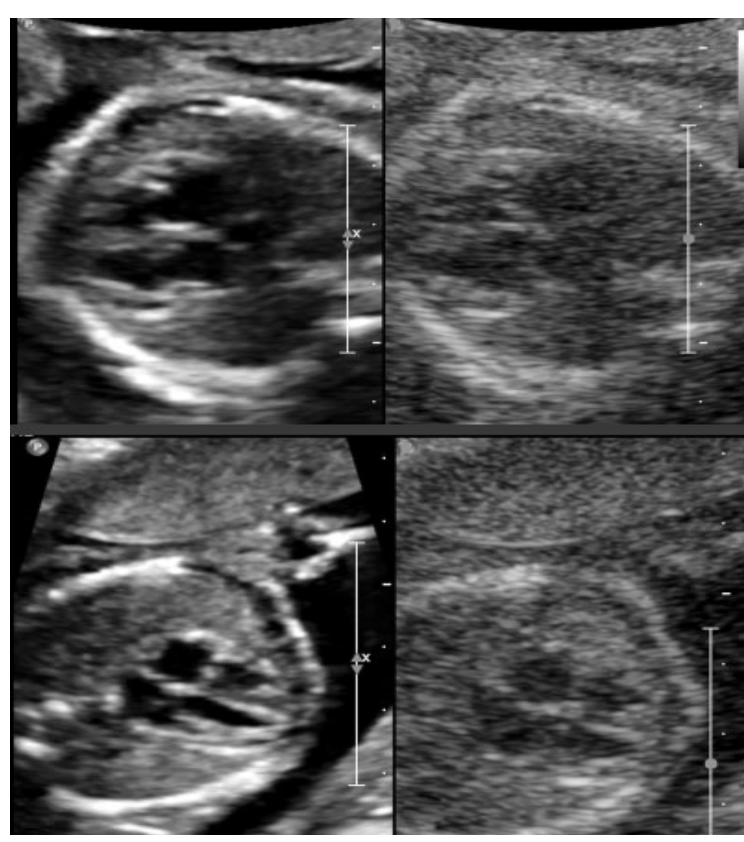

Slika 4. Četvorokomorni presek fetalnog srca gojazne trudnice sa body mass index-om (BMI) $35 \mathrm{~kg} / \mathrm{m} 2$ u 22. nedelji trudnoće $(\mathrm{a}, \mathrm{b})$ i u gojazne trudnice (BMI, $33 \mathrm{~kg} / \mathrm{m} 2$ ) u 20.nedelji trudnoće (c,d). Slike (a) i (c) su ostvarene korišćenjem i THI, CI i SRI; (b) i (d) su prikazi istovetnih struktura korišćenjem konvencionalnog ultrazvučnog pregleda. Razlika u kvalitetu slike je evidentna, a najizraženija u prikazu na granicama solidnih i površina ispunjenih tečnošću. 
ultrazvučne "buke" (ultrasound speckle noise). Dva piksela iste posmatrane lokacije, ali u 2 sukcesivna frame-a će činiti nejasnoću slike, koja se javlja u toku pomeranja tkiva. Osim pritiska odgovarajućeg dugmeta na ultrazvučnom aparatu, smanjenje persistence-a se postiže i povećanjem PRF-a.

Smanjiti Gain color dopplera da bi se izbegao aliasing.

Da bi postigli najbolju moguću prostornu i vremensku rezoluciju, region of interest (ROI) box smanjiti na najmanju moguću meru.

Color Doppler je od velike pomoći u skriningu i dijagnostici KSB. I ovde važi čuveni princip za Doppler pregled: "ono što vidiš je ono što i dobiješ". On daje precizne odgovore na postavljena pitanja. A "odgovori" koje možemo dobiti su: koji je pravac i smer posmatranog toka krvi, da li ima turbulentnog kretanja krvi, da li postoje šantovi i krvni “jet”-ovi, a njime možemo vizuelizovati i sitne krve sudove. Danas je upotreba color Dopplera u rutinskoj primeni u dijagnostici KSB u svim centrima, a u većini i u skriningu iste. Od kolikog značaja primena color Dopplera može biti u skriningu onih pacijenata gde je vizualizacija srca i njegovih struktura otežana ilustruje (Slika 3).

Noviji ultrazvučni "alati” u prenatalnom skriningu i dijagnostici KSB

Brojne tehnološke inovacije koje su imale za cilj poboljšanje kontrastne rezolucije i prikaza graničnih površina različitih tkiva našle su svoje mesto i u fetalnoj ehokardiografiji. Jedna od njih, Speckle reduction imaging (SRI), redukuje neželjene ultrazvučne artefakte koji se nazivaju speckles. Primenom SRI granica između krvi i tkiva srca se oštrije prikazuje. Tisue harmonic imaging redukuje lateralne artefakte, ali i rezoluciju7. Baziran je na fenomenu nelinearne distozije akustičnog signala na njegovom putu kroz tkiva i organe. Prednosti THI su poboljšana aksijalna rezolucija usled njihove kraće talasne dužine, bolja lateralna rezolucija usled poboljšanog fokusiranja sa visokim frekvencijama i manje artefakata u odnosu na konvencionalni ultrazvuk $^{7}$. To ga čini veoma korisnim u pregledu fetusa gojaznih trudnica ${ }^{8}$ (Slika 4).

Konkretne prednosti u prikazu fetalnog srca generalno se odnose na činjenicu da se površine između krvi i tkiva postaju jasnije, tkivo fetalnih pluća se lakše diferentuje od okolnih tkiva, kao i granica između kičme i okolnih mekih tkiva. Compaund imaging daje jasniju ultrazvučnu sliku, što je posledica činjenice da se ultrazvučni signal iz sonde šalje iz više različitih uglova, a ne samo pod jednim uglom što je slučaj u konvencionalnom ultrazvučnom pregledu. Slika broj 4 prikazuje razliku u kvalitetu ultrazvučne slike kada se primene CI i SRI u odnosu na konvencionalni ultrazvučni pregled.

\section{Pregled srca fetusa gojaznih trudnica}
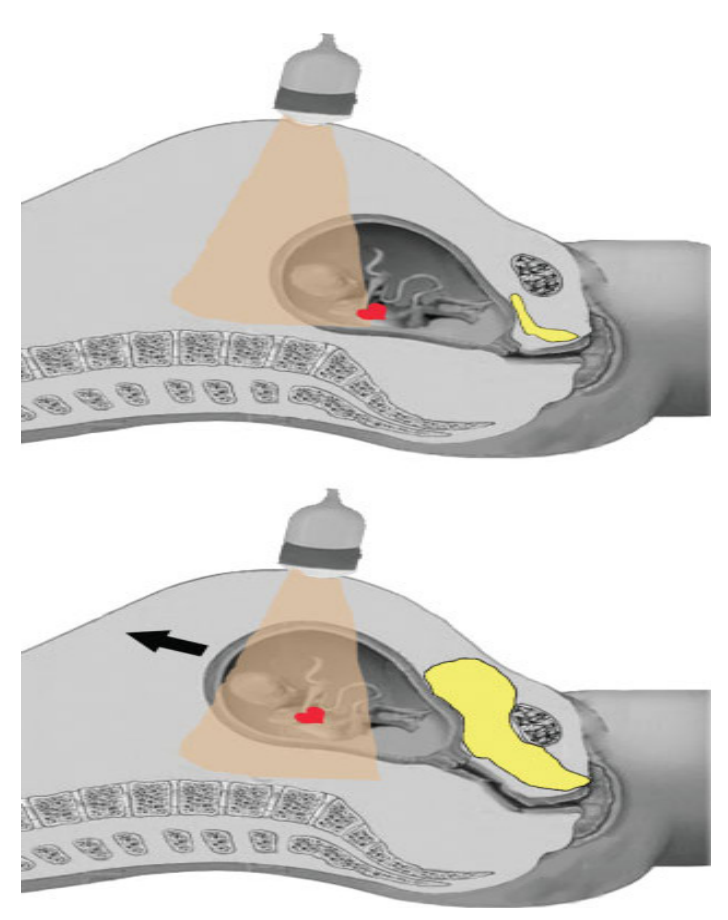

Učestalost gojaznosti je dramatično povećana širom sveta. Ultrazvučni pregled gojaznih trudnica je težak zadak usled pogoršanog akustičkog prozora. Zato je potrebno koristiti niže frekvence ultrazvučnog signala, THI, CI i SRI ${ }^{8}$ (Slika 4). U slučaju karlične prezentacije ploda u gestacionoj starosti kada se obično radi ultrazvučni skrining KSB, korisno je da u momentu pregleda bešika trudnice puna i da se koristi periumbilikalni pristup, što daje bolji pregled fetalnog srca (Slika 5).

Slika 5. (preuzeto iz reference 8) Ultrazvučni pregled srca fetusa sa karličnom prezentacijom transabdominalnim periumbilikalnim pristupom u 20. nedelji gestacije. (a) sa praznom maternalnom bešikom (žuto), srce je izvan "vidnog polja" $i$ teško se evaluira; (b) sa punom mokraćnom bešikom (žuto), uterus je potisnut ka gore, dozvoljavajući bolji pregled fetalnog srca. 


\section{Literatura}

1. Lee W, Carvalho JS, Chaoui R, Copel J, Devore G, Hecher K, Munoz H, Nelson T, Paladini D, Yagel S. ISUOG consensus statement: what constitutes a fetal echocardiogram? Ultrasound Obstetric Gynecol 2008 Aug;32(2):239-42.

2. Friedman Z. The physics of ultrasound imaging. In Yagel S, Silverman NH, Gembruch U. Fetal Cardiology 2003 Martin Dunitz, London, UK.

3. Drose JA. Scanning: Indications and Technique. In: Drose JA. Fetal Echocardiography. W.B. Saunders Company, Philadelphia, 1998; 15-57.

4. Rychik J, Ayres N, Cuneo B, Gotteiner N, Hornberger L, Spevak PJ, Van Der Veld M. American Society of Echocardiography Guidelines and Standards for Performance of the Fetal Echocardiogram. J Am Soc Echocardiogr 2004;17:803-10.

5. Chaoui R, McEwing R. Three cross-sectional planes for fetal color Doppler echocardiography. Ultrasound Obstet Gynecol 2003; 21: 81-93.

6. Ashoush S, El-Nagar A. The technique and Value of Doppler Ultrasonography. ASJOG 2005; 2: $403-6$.

7. Choudhry S, Gorman B,Charboneau JW,Tradup DJ, Beck RJ, Kofler JM, Groth DS. Comparison of Tissue Harmonic Imaging with Conventional US in Abdominal Disease. July-August 2000 RG n Volume 20 • Number 4: 1127- 1135.

8. Paladini D. Sonography in obese and overweight pregnant women: clinical, medicolegal and technical issues.Ultrasound Obstet Gynecol 2009; 33: 720-729

Autor za korespondenciju Prof.dr sci.med. Amira Fazlagić e-mail:mimaf@eunet.rs Karađorđeva 6/32, Zemun 